\title{
PENGEMBANGAN MEDIA PEMBELAJARAN MATEMATIKA “MINITIM KABAR" UNTUK MENINGKATKAN HASIL BELAJAR KOGNITIF SISWA
}

\author{
Zania Ramadani ${ }^{1}$, Wuli Oktiningrum ${ }^{2}$ \\ 1Program Studi PGSD Universitas Islam Raden Rahmat Malang \\ 2Universitas Islam Raden Rahmat Malang \\ zania.ramadani0401@gmail.com
}

\begin{abstract}
:
Weight measurement mathematics was an important material for weighing objects in everyday life. Based on the resulted of observations of students' scores on weight measurement 58\% did not reach the KKM (Minimum Completeness Criteria). This study aim to (1) developing Minitim Kabar media for 2nd grade; (2) knowing the feasibility of "Minitim Kabar" media; (3) knowing the increased in cognitive learning outcomes measuring weight in Class II SD students. This research was R\&D which includes 10 steps in research which include: research potentials and problems, design data, design validation, revision design, product testing, product revision, usage testing, product revision, product production. The expert tested subjects in this study were the media expert validator and the material expert validator, while the tested subjects were 6 students in the media trial and 9 students in the product trial. Data tested techniques using interviews, observation, tests, and documentation. The data analysis technique used quantitative data analysis techniques and qualitative data analysis. The resulted of this study indicate that the mini media had a high level of validity and attractiveness. The resulted of the validation of material experts were $92.3 \%$, the resulted of the validation of media experts were $87.5 \%$, and the proportion of student questionnaire responses was $100 \%$. The increase in students' cognitive learning outcomes was 45.06. The N-gain test result of 0.65 was at a moderate level. Thus, the Minitim Kabar media was suitable for used as a thematic learning media to improve cognitive learning outcomes in 2nd grade on weight measurement matters.
\end{abstract}

Keywords: Mintim Kabar Media, Measurement, Cognitive Learning Outcomes

\section{PENDAHULUAN}

Mata pelajaran matematika khususnya pengukuran berat merupakan materi yang penting untuk menimbang berat benda dalam kehidupan sehari-hari. Menurut Aini (2017: 1) pengukuran berat sangat diperlukan dalam kehidupan sehari-hari. Maka diperlukan patokan agar tidak melenceng antara satu dengan yang lainnya atau jumlah berat sama antara satu dengan lainnya. Oleh karena itu, sistem baku yang telah ditetapkan oleh SI (Systeme International d'Unites) digunakan dalam ukuran panjang, berat dan isi. Satuan ukuran tersebut dilambangkan meter untuk satuan panjang, kilogram untuk berat, dan liter untuk isi (Maizar, 2016: 2). Satuan ukur tersebut sering digunakan salah satunya dalam hal jual beli, maka dari itu manusia harus benar-benar memahaminya untuk menghindari terjadinya kecurangan (Masyithoh, 2014: 5).

Materi pengukuran berat sebenarnya banyak diterapkan siswa dalam kehidupan sehari-hari, akan tetapi siswa belum memahami pengukuran berat 
dengan satuan kilogram, ons, ataupun gram. Hal itu diketahui dari hasil observasi pada perolehan nilai siswa pada materi pengukuran berat dengan satuan baku. $58,3 \%$ siswa mendapat nilai di bawah KKM (Kriteria ketuntasan Minimal), dengan KKM yang ditentukan guru adalah 70. Rendahnya hasil belajar siswa menjadi petunjuk adanya kelemahan sekaligus kesulitan belajar, yang dalam hal ini berarti ada kelemahan dan kesulitan belajar pada materi pengukuran berat dengan satuan baku.

Berdasarkan hasil wawancara pada guru kelas II pada bulan Januari 2020 selama ini pembelajaran pada materi pengukuran berat dengan satuan baku diawali dengan menunjukkan alat ukur berupa timbangan kue untuk mengenalkan alat ukur berat dan satuannya, akan tetapi siswa belum paham dengan materi satuan pengukuran berat. Kemudian siswa diminta untuk menggambar tangga di buku tulis untuk mengubah satuan gram, ons, dan kilogram dengan contoh tangga satuan di papan tulis. Satuan yang terdapat pada tangga bersifat abstrak sehingga membutuhkan penjelas dari konsep tersebut. Siswa dalam mengerjakan soal yang berkaitan dengan satuan pengukuran menggunakan tangga satuan dapat memakan waktu yang cukup lama (Ashikin 2018: 3). Hal tersebut menunjukkan bahwa siswa kesulitan mengerjakan soal menggunakan tangga satuan. Menurut (Piaget dalam Herliani and Heryati 2017: 63) anak pada usia 7 sampai 12 tahun berada pada tahap operasional konkret, artinya mampu berpikir logis mengenai objek dan kejadian meskipun masih terikat objek-objek yang bersifat konkret sehingga dalam pembelajarannya siswa harus terlibat dalam benda-benda yang nyata. Siswa yang tidak memahami maka berdampak pada hasil belajar matematika yang kurang memuaskan. Terutama pada materi pengukuran berat.

Menurut guru kelas II SD, rendahnya hasil belajar matematika pada materi pengukuran berat juga dikarenakan beberapa faktor, yaitu faktor internal dan faktor eksternal. Faktor internal yaitu faktor yang berasal dari dalam diri siswa, yaitu siswa mengalami kesulitan dalam memahami konsep pengukuran berat karena terdapat beberapa satuan yang bersifat abstrak. Siswa belum paham $100 \%$ makna satuan kilogram, ons, dan gram. Faktor eksternal yaitu faktor yang dapat mempengaruhi hasil belajar siswa yang berasal dari luar siswa, seperti kurangnya perhatian orang tua dalam mengawasi belajar anaknya di rumah karena sibuk bekerja sehingga sulit untuk memaksimalkan potensi anak. Menurut Ardila and Hartanto (2017: 8) ada beberapa faktor yang mempengaruhi rendahnya hasil belajar matematika siswa, yaitu siswa kurang berminat terhadap pelajaran matematika, siswa tidak berkonsentrasi selama pembelajaran, rendahnya pemahaman konsep matematika dasar siswa, dan kurangnya kediplinan siswa.

Salah satu cara yang dapat dilakukan untuk mengatasi kesulitan siswa pada materi pengukuran berat adalah dengan memberikan bantuan belajar kepada siswa yang tidak memahami materi pengukuran berat dengan satuan baku. Media juga dibutuhkan untuk menghantarkan konsep pengukuran berat dengan satuan baku kepada siswa. Satuan baku seperti gram, ons, dan kilogram merupakan materi yang abstrak, sehingga dalam penyampaian pada siswa membutuhkan cara belajar dari pengalaman langsung yang diperoleh siswa pada tahap enactive bertujuan agar daya serap siswa tinggi sehingga benar-benar melekat di otak (Aisyah 2017: 16). Menurut Daryanto (2010: 30) anak dapat belajar melalui model untuk pokok bahasan tertentu yang tidak mungkin dilakukan melalui pengalaman

Alifmatika: Jurnal Pendidikan dan Pembelajaran Matematika, Desember 2020, Vol. 2, No. 2 
langsung atau melalui benda sebenarnya yang dimaksud model yaitu media tiruan yang termasuk dalam media tiga dimensi. Menurut Handayani and Alamsyah (2017: 1) bahwa media timbangan dapat meningkatkan aktivitas dan hasil belajar siswa kelas II SD.

Berdasarkan uraian di atas, peneliti ingin mengembangkan media Minitim Kabar (Miniatur Timbangan Kartu Bergambar) untuk meningkatkan hasil belajar kognitif materi pengukuran berat. Media Minitim Kabar (Miniatur Timbangan Kartu Bergambar) yaitu media visual 3 dimensi untuk menimbang dengan satuan gram, ons, dan kilogram dengan kartu bergambar yang ukurannya sudah dimanipulasi dan disesuaikan. Peneliti menggunakan beberapa jenis kartu yaitu kartu timbal(untuk pemberat) yang berisi satuan, kartu konversi untuk mengubah satuan, dan kartu soal untuk latihan siswa. Peneliti memilih menambah media kartu karena kartu mudah digunakan dan dapat diberi gambar yang menarik.

\section{METODE PENELITIAN}

Jenis penelitian yang dilakukan yaitu R\&D (research and development Langkah-langkah pengembangan produk minitim kabar mengikuti langkahlangkah Sugiyono (2015: 72) yang terdiri dari: (1) potensi dan masalah; (2) pengumpulan data; (3) desain produk; (4) validasi desain; (5) revisi desain; (6) uji coba produk; (7) revisi produk; (8) uji coba pemakaian; (9) revisi produk; dan (10) produksi produk.

Subjek uji ahli pada penelitian ini yaitu validator ahli media dan validator ahli materi, sedangkan subjek uji coba yaitu 6 siswa SDN Kebonagung II pada uji coba media dan 9 siswa Desa Genengan pada uji coba produk. Penelitian uji coba media dilakukan pada hari Kamis, 27 Februari 2020, sedangkan pada uji coba pemakaian dilakukan hari Selasa, 21 April 2020. Teknik pengumpulan data yang digunakan dalam penelitian pengembangan ini berupa wawancara, observasi, tes, dan dokumentasi.

Prosedur penelitian yang dilakukan ada beberapa tahap yaitu (1) potensi dan masalah, yaitu melakukan observasi dan wawancara kepada guru kelas II SD untuk memperoleh informasi mengenai pembelajaran di kelas II dan permasalahan yang dihadapi siswa dalam belajar; (2) yaitu pengumpulan data, yaitu kajian pustaka mengenai materi pengukuran berat dengan satuan baku dan kajian jenis media yang sesuai sebagai referensi pengembangan media selanjutnya; (3) desain produk yaitu membuat desain Minitim Kabar (miniatur timbangan kartu bergambar), konsultasi dan revisi, dan pembuatan media; (4) validasi desain kepada ahli materi dan ahli media untuk mengetahui kelayakan media Minitim Kabar; (5)revisi desain, yaitu perbaikan media sesuai saran validator; (6)uji coba media, yaitu melakukan uji coba terbatas pada 6 siswa SDN Kebonagung II. (7)revisi produk berdasarkan uji coba media; (8) uji coba pemakaian media Minitim kabar pada 9 siswa kelas II SD (random) di Desa Genengan; (9)revisi produk berdasarkan hasil uji coba pemakaian (apabila ada yang perlu direvisi); dan (10)produksi produk yaitu melakukan produksi media sesuai kebutuhan.

Produk (media Minitim Kabar) yang dikembangkan dinilai kualitasnya yang meliputi aspek validitas, kepraktisan, dan keefektifan. Aspek validitas dinilai dengan validasi ahli materi, aspek kepraktisan dinilai dengan angket respon siswa,

Alifmatika: Jurnal Pendidikan dan Pembelajaran Matematika, Desember 2020, Vol. 2, No. 2 
dan aspek keefektifan dinilai dengan uji eksperimen dengan menggunakan bentuk desain pre-experimental one group pretest-posttest untuk mengujicobakan media.

\section{Analisis Kelayakan Produk Aspek Validitas}

Aspek validitas dinilai untuk mengetahui kelayakan produk. Aspek yang dinilai pada validitas media yaitu aspek penggunaan dan aspek tampilan. Aspek yang dinilai pada validitas materi yaitu aspek materi dan penyajian. Setiap aspek baik dalam validasi media maupun materi, tingkat kevalidannya diukur dengan menggunakan rating scale yaitu rentang skor 1-4. Skor 1 berarti kurang, skor 2 berarti cukup, skor 3 berarti baik, dan skor 4 berarti sangat baik (Sugiyono, 2011: 93). Validitas media dinilai oleh validator ahli media, yaitu Bapak Andi Wibowo, M.Pd sedangkan validitas materi dinilai oleh validator ahli materi yaitu Ibu Ike Novia, S.Pd.

Analisis kelayakan produk yang dilakukan yaitu mencari rata-rata dari angket validasi kemudian dikualifikasikan pada tingkat kelayakan produk disajikan pada Tabel 1 berikut.

Tabel 1. Kualifikasi Tingkat Kelayakan dari Presentase Rata-Rata

\begin{tabular}{ccc}
\hline Presentase (\%) & Kualifikasi & Kriteria Kelayakan \\
\hline $90-100$ & Sangat baik & Sangat layak, tidak perlu direvisi \\
$75-89$ & Baik & Layak, tidak perlu direvisi \\
$65-74$ & Cukup & Cukup layak, perlu direvisi \\
$55-64$ & Kurang & Kurang layak, perlu direvisi \\
$0-54$ & Sangat kurang & Tidak layak, revisi total \\
\hline
\end{tabular}

(Arifin 2016: 236)

Berdasarkan kriteria di atas, media pembelajaran dikatakan layak jika memenuhi kriteria skor $\geq 75$ dengan aspek penggunaan dan aspek tampilan, aspek materi dan penyajian.

\section{Aspek Kepraktisan}

Aspek Kepraktisan dinilai oleh pengguna (siswa). Penilaian media Minitim Kabar terhadap siswa terdapat 5 aspek indikator yang dijabarkan pada 2 aspek penggunaan media, 2 aspek pemahaman materi , 2 aspek visual, 3 aspek minat dan motivasi, dan 1 aspek kepraktisan media. Setiap aspek diukur dengan menggunakan skala Guttman. Rentang skor pada skala Guttman adalah 0-1, jawaban tidak berarti mendapatkan skor 0, dan jawaban iya berarti mendapatkan skor 1 (Sugiyono, 2015: 96). Komponen-komponen pada setiap aspek dihitung presentasenya kemudian dikualifikasikan dengan kriteria kelayakan produk.

\section{Aspek Keefektifan}

Aspek keefektifan dinilai dengan uji eksperimen kepada siswa dengan menggunakan bentuk desain pre-experimental one group pretest-posttest untuk menguji cobakan media. Desain tersebut dapat digambarkan seperti berikut.

Alifmatika: Jurnal Pendidikan dan Pembelajaran Matematika, Desember 2020, Vol. 2, No. 2 


\section{$\mathrm{O}_{1} \times \mathrm{O}_{2}$}

Gambar 1. One-group pretest-posttest design (Sugiyono 2015: 75)

Keterangan:

$\boldsymbol{O}_{\boldsymbol{1}}=$ Nilai pretest (sebelum menggunakan media minitim kabar)

$\boldsymbol{X}=$ Treatment yang diberikan

$\boldsymbol{O}_{2}=$ Nilai pretest (sebelum menggunakan media minitim kabar)

Teknik analisis data menggunakan eksperimen One-Grop Pretest-Posttest Design yaitu membandingkan dengan keadaan sebelum dan setelah diberi perlakuan.

1. Menghitung rata-rata skor dari total skor pretest dan posttest:

Keterangan:

$$
M e=\frac{\sum x}{n}
$$

$$
\begin{array}{ll}
\mathrm{Me} & =\text { Mean (rata-rata) } \\
\sum x & =\text { jumlah skor } \\
n & =\text { jumlah siswa (Rufayda, 2013: 64) }
\end{array}
$$

2. Uji $N$-gain untuk mengetahui peningkatan hasil belajar siswa

$<g>=\frac{S f-S i}{\text { Skor maksimal-Si }}$

Keterangan:

$<g>\quad=$ gain

$\mathrm{Sf}=$ nilai rata-rata kelas akhir

$\mathrm{Si}=$ nilai rata-rata kelas mula-mula

Tabel 2. Kriteria Peningkatan Hasil Belajar

\begin{tabular}{cc}
\hline Nilai Kuantitatif & Nilai Kualitatif \\
\hline$N$-gain $<0,3$ & Rendah \\
$0,7 \geq N$-gain $\geq 0,3$ & Sedang \\
$N$-gain $>0,7$ & Tinggi \\
\hline
\end{tabular}

(Hake dalam Widayanti et al., 2016: 3)

3. Persentase hasil belajar siswa melalui aspek kognitif pada masing-masing siswa dihitung dengan rumus:

$$
P=\frac{\text { jumlah skor }}{\text { skor maksimal }} \times 100 \%
$$

\section{HASIL PENELITIAN}

\section{Pengembangan Media Pembelajaran}

Tahap pertama adalah potensi dan masalah. Berdasarkan hasil wawancara pada guru kelas II pada bulan Januari 2020, pembelajaran pengukuran satuan baku diawali dengan menunjukkan alat ukur berupa timbangan kue, kemudian untuk mengubah satuan gram, ons, dan kilogram dengan menggambar tangga pada papan tulis. Siswa harus mengamati dan memahami konsep naik dan turun pada 
tangga pengukuran berat tersebut. Satuan yang terdapat pada tangga bersifat abstrak sehingga membutuhkan penjelas dari konsep tersebut. Siswa dalam mengerjakan soal yang berkaitan dengan satuan pengukuran menggunakan tangga satuan dapat memakan waktu yang cukup lama (Ashikin 2018: 3). Menurut (Piaget dalam Herliani and Heryati 2017: 63) anak pada usia 7 sampai 12 tahun berada pada tahap operasional konkret, artinya mampu berpikir logis mengenai objek dan kejadian meskipun masih terikat objek-objek yang bersifat konkret.

Tahap kedua yaitu pengumpulan data, yaitu mengenai berbagai informasi yang dapat digunakan sebagai bahan untuk perencanaan produk tertentu yang diharapkan dapat mengatasi masalah tersebut. Peneliti melakukan kajian terhadap teori-teori maupun hasil penelitian terdahulu yang berkaitan dengan rancangan pengembangan produk dan media pembelajaran.

Tahap ketiga yaitu desain produk, peneliti mengembangkan bentuk awal media Minitim Kabar materi pengukuran berat. Media minitim kabar terdiri dari beberapa bagian yaitu timbangan, kartu (kartu timbal, kartu konversi, dan kartu soal) dan replika benda-benda konkrit untuk ditimbang. Berikut uraian produk yang dikembangkan:

Tuas Timbangan

Tuasnya timbangan mempunyai gambar yang didesain dengan menggunakan aplikasi Microsoft Power Point. Gambar ini didesain dengan ukuran panjang $35 \mathrm{~cm}$ dengan tinggi $10 \mathrm{~cm}$ berbahan dasar kertas stiker.

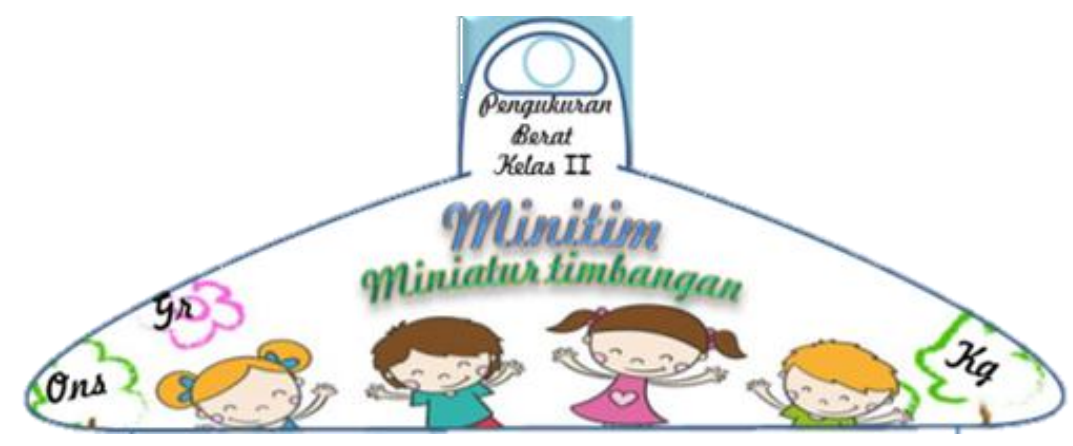

Gambar 2. Desain Awal Miniatur Timbangan

Desain Kartu Bergambar

Kartu bergambar yang berupa kartu timbal terbuat dari kertas HVS yang dilapisi dengan kertas karton. Bagian yang paling luar dilapisi dengan plastik bening untuk melindungi agar gambar tidak mudah luntur. Kartu bergambar terdiri dari tiga bagian, yaitu kartu timbal, kartu konversi, dan kartu soal:

Desain Kartu Timbal

Kartu timbal didesain dengan menggunakan aplikasi microsoft word. Kartu bergambar yang berupa kartu timbal memiliki ukuran yang berbeda-beda yaitu:

50 gram $=(5 \mathrm{~cm} \times 5 \mathrm{~cm}) \times 2$ lembar

100 gram $=(6,25 \mathrm{~cm} \mathrm{x} 4 \mathrm{~cm}) \times 4$ lembar

200 gram $=(8 \mathrm{~cm} \times 5 \mathrm{~cm}) \times 5$ lembar

250 gram $=(10 \mathrm{~cm} \times 5 \mathrm{~cm}) \times 5$ lembar

500 gram $=(12,5 \mathrm{~cm} \times 8 \mathrm{~cm}) \times 5$ lembar

$1 \mathrm{~kg}=(12,5 \mathrm{~cm} \times 10 \mathrm{~cm}) \times 8$ lembar

Alifmatika: Jurnal Pendidikan dan Pembelajaran Matematika, Desember 2020, Vol. 2, No. 2 
Berikut ini disajikan gambar kartu timbal:

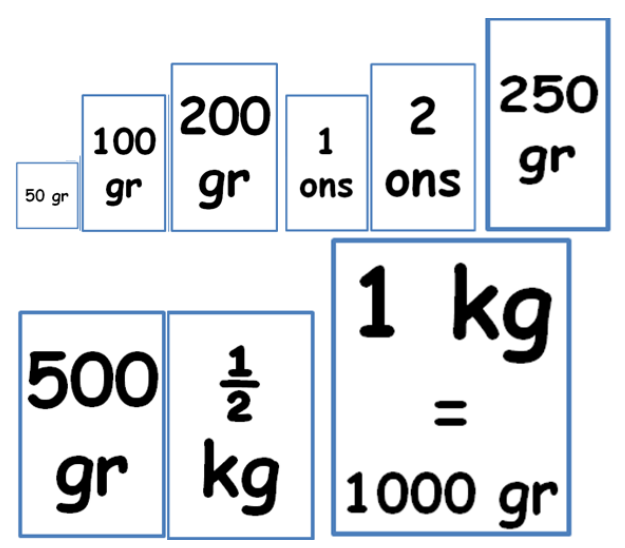

Gambar 3. Desain Awal Kartu Timbal

Desain Kartu Konversi

Kartu konversi terbuat dari kertas HVS yang di print kemudian dilaminating dengan tujuan agar tidak mudah rusak. Kartu konversi berukuran $10 \mathrm{~cm} \times 5 \mathrm{~cm}$. Berikut ini disajikan gambar desain kartu konversi.

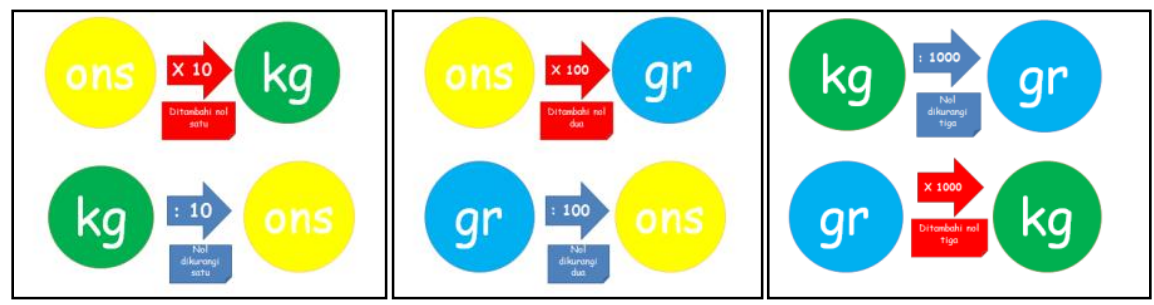

Gambar 4. Desain Awal Kartu Konversi

Desain Kartu Soal

Kartu Soal memiliki ukuran 12,5 $\mathrm{cm} \times 9,5 \mathrm{~cm}$. Kartu soal berisi tentang berbagai macam pertanyaan tentang pengukuran berat yang harus diselesaikan oleh siswa secara berkelompok. Jenis pertanyaan berupa soal uraian (essay). Desain kartu soal disajikan pada berikut ini:

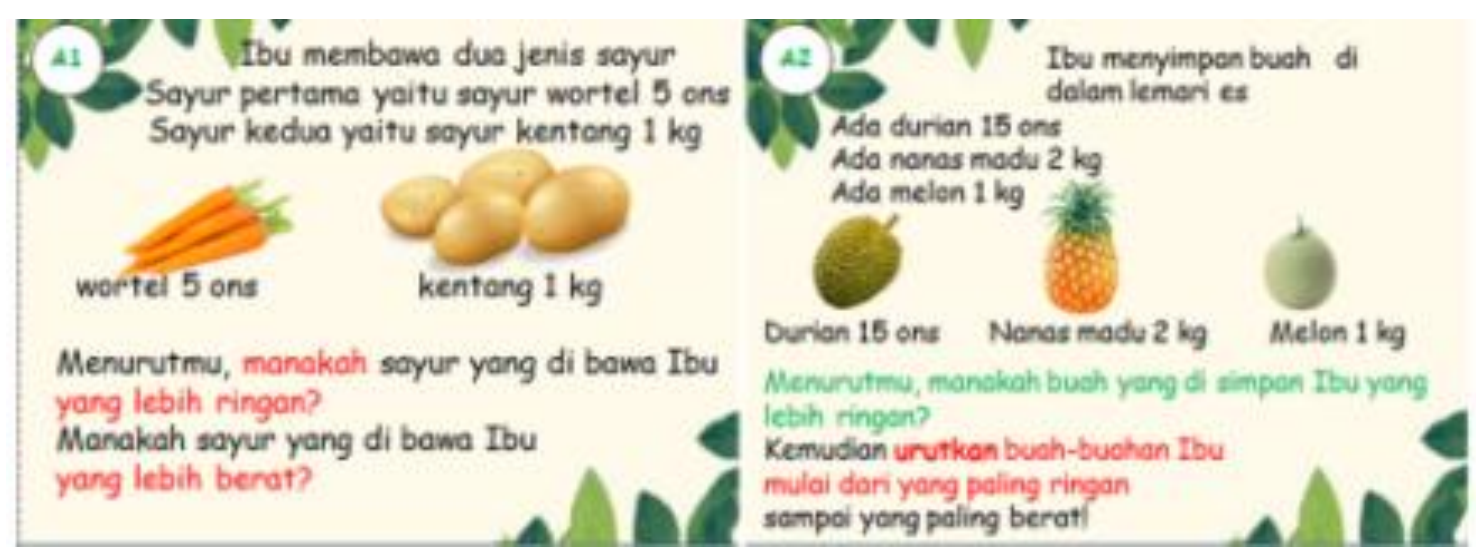

Alifmatika: Jurnal Pendidikan dan Pembelajaran Matematika, Desember 2020, Vol. 2, No. 2 


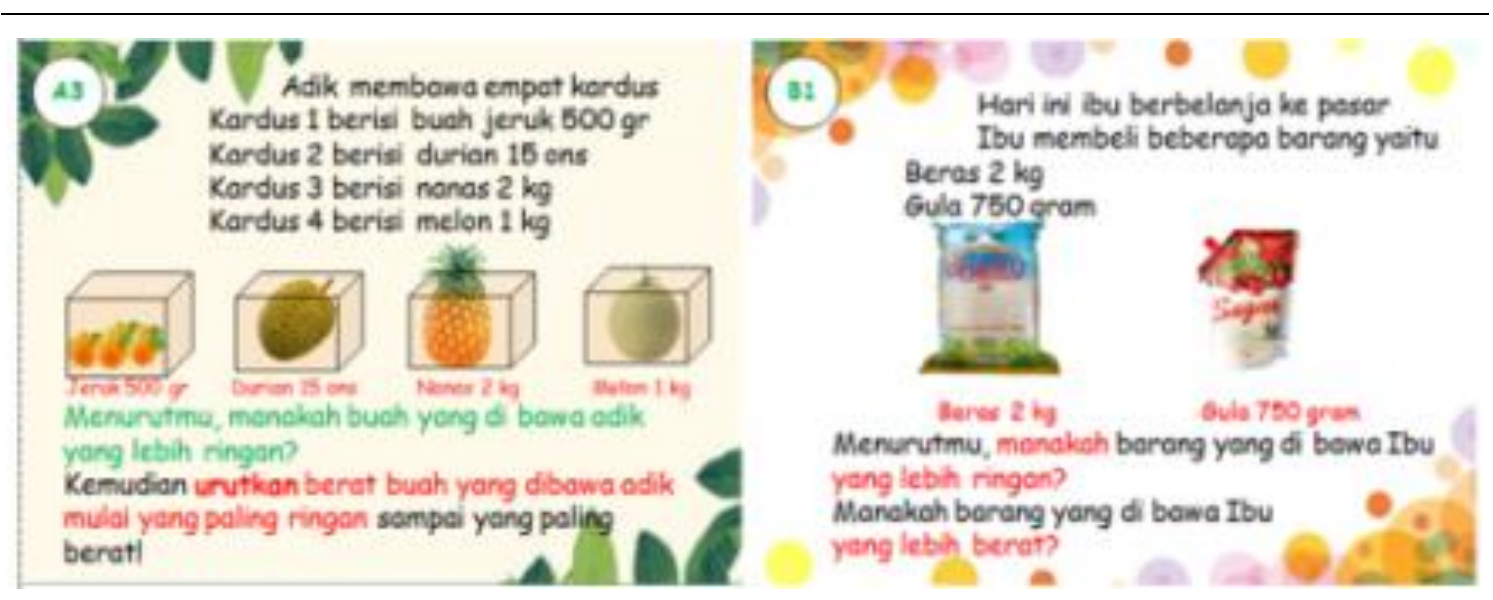

Gambar 5. Desain Awal Kartu Soal

Replika Benda-benda Konkrit untuk ditimbang

Replika benda-benda konkret untuk ditimbang bervariasi, yaitu buah-buahan yang terbuat dari plastik yang diisi dengan pasir, ukuran buah-buahan juga berbeda-beda. Gula dan beras yang ditimbang sudah disiapkan di dalam kertas yang dilapisi dengan plastik dan ukurannya disesuaikan dengan berat timbal pada miniatur timbangan. Gambar replika benda konkrit disajikan berikut ini.

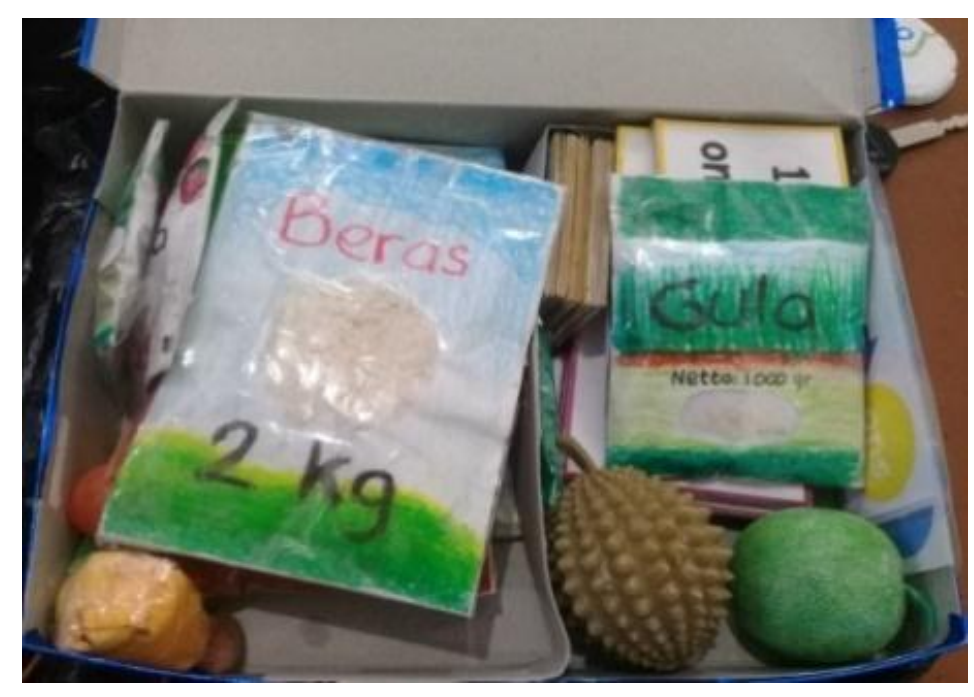

Gambar 6. Replika Benda Konkrit untuk ditimbang

Media Minitim Kabar juga disertai dengan buku panduan untuk memudahkan siswa dalam menggunakan atau dapat dijadikan petunjuk penggunaan media. Buku panduan penggunaan media berbentuk booklet dengan ukuran 10,5 cm $\times 14,35 \mathrm{~cm}$. Pada Gambar 7 dan 8 berikut ini disajikan desain sampul dan isi buku panduan.

Alifmatika: Jurnal Pendidikan dan Pembelajaran Matematika, Desember 2020, Vol. 2, No. 2 


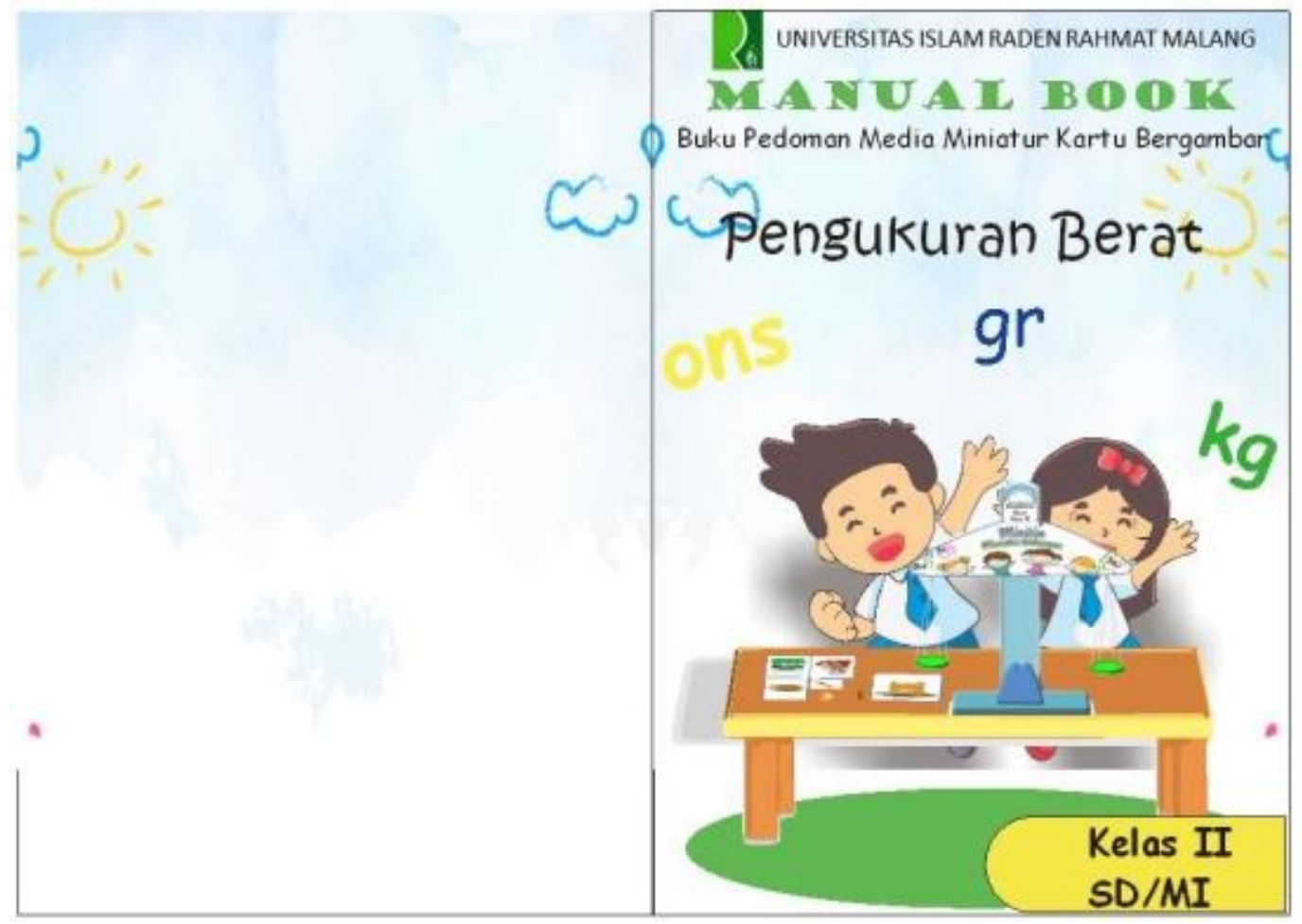

Gambar 7. Desain Sampul Buku Panduan
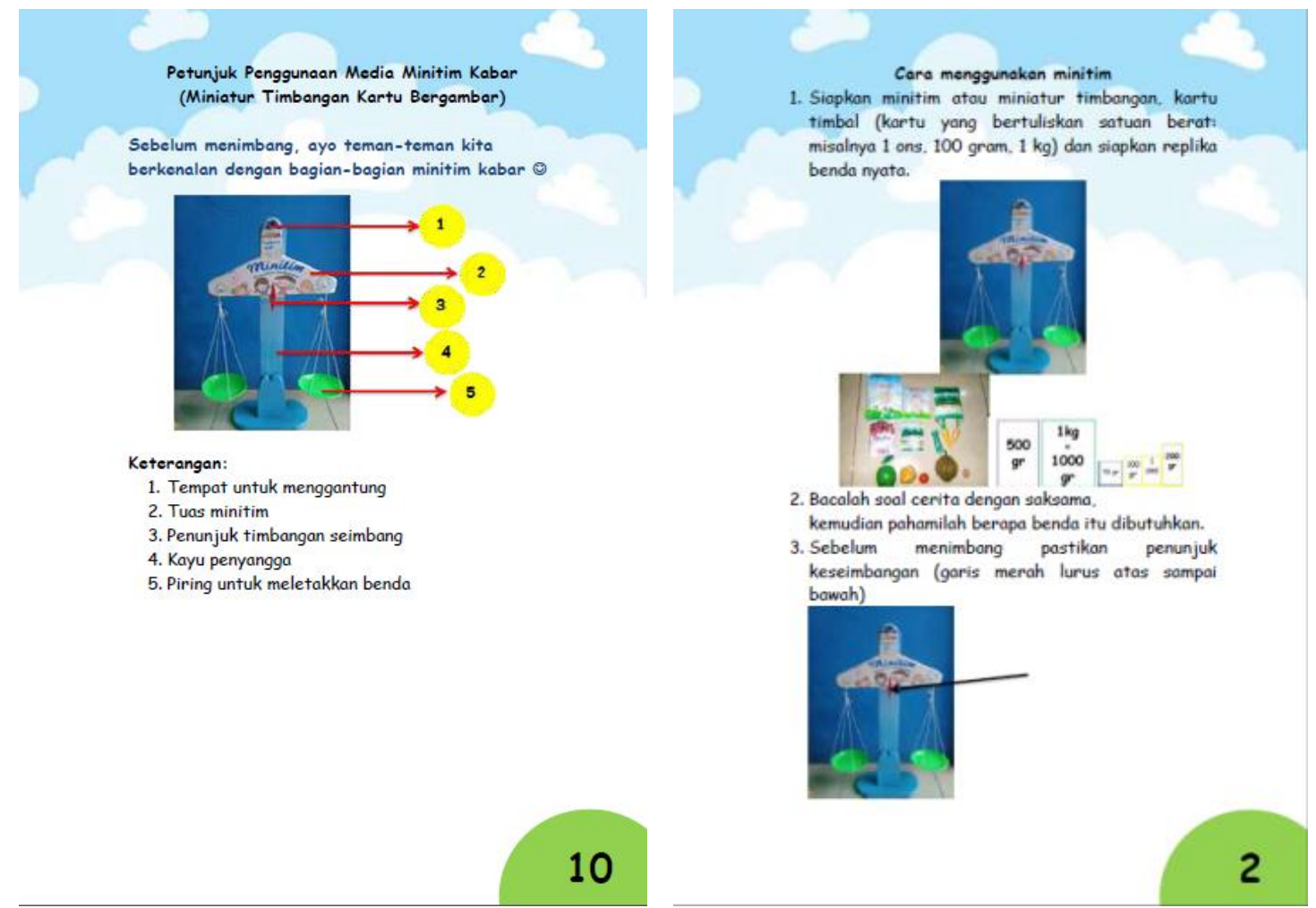

Gambar 8. Desain Buku Panduan Bagian Dalam

Alifmatika: Jurnal Pendidikan dan Pembelajaran Matematika, Desember 2020, Vol. 2, No. 2 


\section{Kelayakan Media Minitim Kabar (Miniatur Timbangan Kartu Bergambar) Validasi Ahli Materi}

Validator ahli materi dalam media minitim kabar yaitu Ibu Ike Novia A., M.Pd guru Guru SDN 2 Kebonagung. Validasi media kepada ahli materi dilakukan pada tanggal 25 Februari 2020. Ada 2 aspek dalam validasi ahli materi yaitu materi dan penyajian. Rata-rata yang diperoleh pada aspek materi yaitu 100, sedangkan ratarata aspek penyajian yaitu 83,3. Secara keseluruhan hasil validasi mendapatkan rata-rata 91,6. Berdasarkan pedoman konversi data kuantitatif ke kualitatif, maka produk media minitim kabar yang dikembangkan masuk ke dalam kriteria sangat baik sehingga media sangat layak digunakan dan tidak perlu revisi.

\section{Validasi Ahli Media}

Validator ahli media dalam media minitim kabar yaitu Bapak Andi Wibowo, M.Pd dosen Pendidikan Guru Sekolah Dasar Fakultas Psikologi dan Ilmu Pendidikan Universitas Islam Raden Rahmat Malang. Validasi media kepada ahli media dilaksanakan pada tanggal 24 Februari 2020. Terdapat 2 aspek dalam validasi ahli media, yaitu penggunaan dan tampilan. Hasil rata-rata aspek penggunaan mendapatkan rata-rata 86,1, sedangkan aspek tampilan mendapatkan rata-rata 88,63. Secara keseluruhan hasil validasi mendapatkan rata-rata 87,5. Berdasarkan pedoman konversi data kuantitatif ke kualitatif, maka produk media minitim kabar yang dikembangkan masuk ke dalam kriteria baik. Meskipun demikian, masih terdapat beberapa yang perlu diperbaiki. Berikut ini disajikan hasil revisi tampilan media.

\section{Tabel 3. Tampilan Media Sesudah Revisi}

\begin{tabular}{l}
\hline \multicolumn{3}{c}{ Sesudah Revisi } \\
$\begin{array}{l}\text { Benda yang ditimbang sudah } \\
\text { berbentuk } 3 \text { dimensi sehingga tidak } \\
\text { menyebabkan salah konsep pada } \\
\text { siswa }\end{array}$
\end{tabular}

\section{Angket respon siswa}

Angket respon siswa digunakan untuk memperoleh informasi mengenai respon siswa dan kelayakan dalam hal kepraktisan tentang media yang dikembangkan. Presentase yang diperoleh yaitu 100\%, artinya media minitim kabar dalam segi penggunaan media, kemudahan pemahaman materi, visual(tampilan), minat dan motivasi, serta kepraktisan media sudah baik dan sesuai dengan kriteria kelas II Sekolah Dasar. Selanjutnya, pada uji coba pemakaian media dengan 9 responden mendapatkan hasil yang sama. Presentase yang diperoleh sebanyak 100\%, artinya media minitim kabar dalam segi

Alifmatika: Jurnal Pendidikan dan Pembelajaran Matematika, Desember 2020, Vol. 2, No. 2 
penggunaan media, kemudahan pemahaman materi, visual (tampilan), minat dan motivasi, serta kepraktisan media sudah baik dan sesuai dengan kriteria kelas II Sekolah Dasar.

\section{Peningkatan Hasil Belajar Belajar Kognitif Siswa Pada Materi Pengukuran Berat \\ Uji Coba Produk}

Uji coba produk (uji coba terbatas kelompok kecil) dilakukan pada hari Kamis pada tanggal 27 Februari 2020. Responden dalam uji coba produk adalah 6 orang siswa kelas II A SDN Kebonagung 2 Malang. Subjek uji coba di kelas.

Rata-rata hasil pretest siswa sebesar 31,3 dan hasil posttest sebesar 74,83. Peningkatan rata-rata hasil belajar siswa pada aspek kognitif (C1-C6) sebesar 43,53. Presentase peningkatan hasil belajar kognitif setiap indikator mulai C1 sampai C6 disajikan pada Gambar 9 di bawah ini.

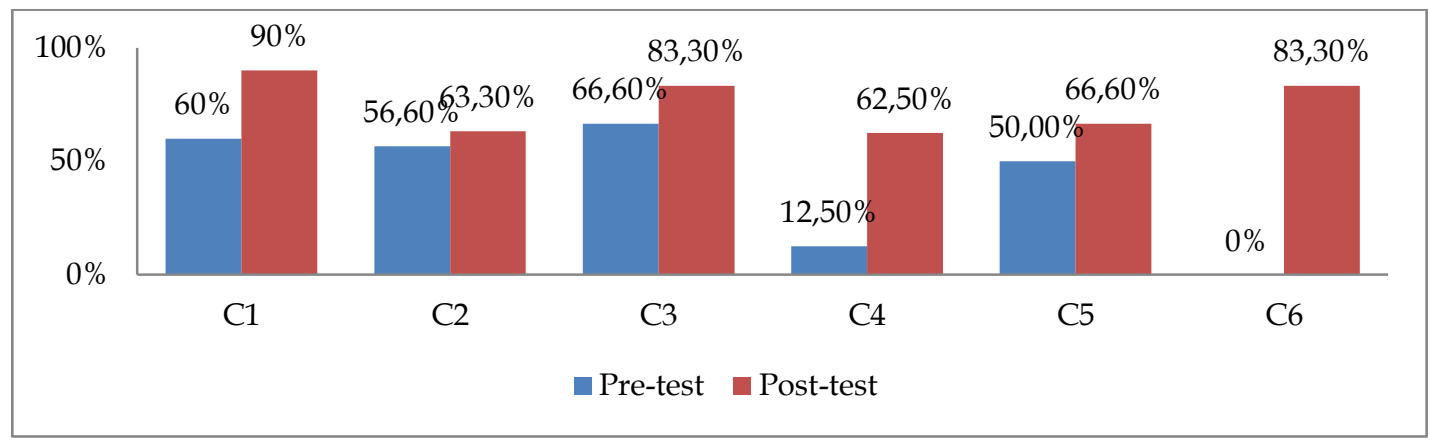

Gambar 9. Presentase Hasil Belajar Kognitif Uji Coba Produk

Berdasarkan Gambar 9 dapat diketahui bahwa setiap indikator ada jumlah presentase peningkatan hasil belajar antara sebelum dan sesudah menggunakan media. Selanjutnya uji $N$-Gain pada tahap uji coba produk untuk mengetahui peningkatan hasil belajar penggunaan media minitim kabar. Hasil Uji $N$-Gain uji coba produk disajikan pada Tabel 4 berikut.

Tabel 4. Hasil Uji N-Gain Score Uji Coba Produk

\begin{tabular}{llcccc}
\hline No & Nama & $S f$ - Si & Skor max -Sf & $N$-gain & \\
& & & & & Kriteria \\
\hline $\mathbf{1}$ & RA & 45 & 45 & 1 & Tinggi \\
$\mathbf{2}$ & DW & 42,5 & 60 & 0,7 & Tinggi \\
$\mathbf{3}$ & FNA & 13 & 88 & 0,14 & Rendah \\
$\mathbf{4}$ & MIR & 58,5 & 81 & 0,72 & Tinggi \\
$\mathbf{5}$ & R & 44,5 & 77,5 & 0,57 & Sedang \\
$\mathbf{6}$ & IRO & 57,5 & 60,5 & 0,95 & Tinggi \\
\hline
\end{tabular}

Berdasarkan Tabel 4 di atas Uji N-gain rata-rata kelompok dihitung secara keseluruhan, mendapatkan hasil 0,6 termasuk dalam kategori sedang, maka dapat

Alifmatika: Jurnal Pendidikan dan Pembelajaran Matematika, Desember 2020, Vol. 2, No. 2 
dikatakan bahwa media minitim kabar dapat meningkatkan hasil belajar kognitif siswa materi pengukuran berat kelas II SD.

\section{Uji Coba Pemaikaian}

Uji coba pemakaian merupakan uji coba produk sesudah direvisi pada kelompok siswa yang jumlahnya lebih besar daripada uji coba produk (terbatas). Uji coba pemakaian dilakukan pada hari Rabu pada tanggal 29 April 2020. Responden dalam uji coba pemaikaian adalah 9 orang siswa kelas II di Desa Genengan Kecamatan Pakisaji. Rata-rata hasil pretest siswa sebesar 31,1 dan hasil posttest sebesar 76,16. Peningkatan rata-rata hasil belajar siswa pada aspek kognitif (C1-C6) sebesar 45,06. Presentase hasil belajar disajikan pada grafik di bawah ini.

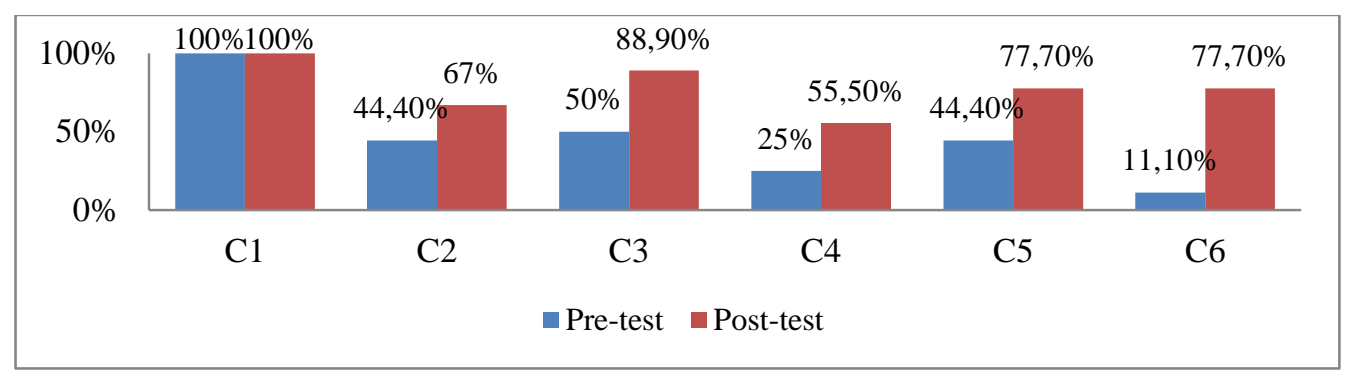

Grafik 10. Presentase Hasil Belajar Uji Coba Pemakaian

Berdasarkan Gambar 10 di atas dapat diketahui bahwa setiap aspek indikator kognitif mengalami peningkatan yang signifikan antara pre-test yaitu sebelum menggunakan media minitim kabar dan post-test atau sesudah menggunakan media minitim kabar. Selanjutnya uji $\mathrm{N}$-Gain pada tahap uji coba produk untuk mengetahui peningkatan hasil belajar penggunaan media minitim kabar. Hasil Uji $N$-Gain uji coba produk disajikan pada Tabel 5 berikut.

Tabel 5. Hasil Uji Gain Score Uji Coba Pemakaian

\begin{tabular}{llcccc}
\hline No & Nama & $S f-S i$ & Skor max $-S f$ & $N$-gain & Kriteria \\
\hline 1 & ABD & 58 & 60,5 & 0,95 & Tinggi \\
2 & ATK & 57,5 & 85 & 0,67 & Sedang \\
3 & ALB & 36,5 & 77,5 & 0,41 & Sedang \\
4 & NMS & 52,5 & 85 & 0,61 & Tinggi \\
5 & FRS & 42,5 & 50 & 0,95 & Tinggi \\
6 & ADN & 34 & 37,5 & 0,9 & Tinggi \\
7 & ZHW & 24,5 & 45,5 & 0,53 & Sedang \\
8 & FLA & 37,5 & 62,5 & 0,43 & Sedang \\
9 & SSA & 57,5 & 83,5 & 0,68 & Sedang \\
\hline
\end{tabular}

Berdasarkan Tabel 5 di atas dapat diketahui bahwa rata-rata kelompok dihitung secara keseluruhan, mendapatkan hasil 0,65 termasuk dalam kategori sedang,

Alifmatika: Jurnal Pendidikan dan Pembelajaran Matematika, Desember 2020, Vol. 2, No. 2 
maka dapat dikatakan bahwa media minitim kabar dapat meningkatkan hasil belajar kognitif siswa materi pengukuran berat kelas II SD.

\section{PEMBAHASAN}

\section{Pengembangan Media Minitim Kabar}

Pengembangan media minitim kabar didasarkan pada permasalahan yang ditemukan oleh peneliti di lapangan yaitu belum adanya media yang dipakai untuk pembelajaran pengukuran berat dengan satuan baku dan nilai hasil belajar siswa pada materi tersebut rendah, sehingga penelitian ini difokuskan pada mengembangkan media pembelajaran matematika yang dapat diintegrasikan dengan pembelajaran tematik yang baik untuk digunakan siswa kelas II SD.

Alasan pemilihan media minitim kabar untuk dikembangkan karena menurut (Munadi 2008: 24) ada faktor-faktor yang mempengaruhi proses dan hasil belajar, yaitu faktor fisiologis dan psikologis. Menurut (Piaget dalam Herliani and Heryati 2017: 59) secara psikologis, siswa kelas II SD termasuk pada tahapan operasional konkret, artinya mampu berpikir logis mengenai objek dan kejadian meskipun masih terikat objek-objek yang bersifat konkret. Pendapat ini diperkuat dengan penelitian Mutrofin and Mudjiarti (2014: 10) bahwa media timbangan dapat meningkatkan aktivitas guru, siswa, dan hasil belajar siswa.

Langkah-langkah pengembangan media minitim kabar didasarkan pada prosedur pengembangan Sugiyono yang terdiri dari 10 tahap, dimulai dari potensi dan masalah hingga produksi produk. Pada tahap terakhir produksi produk.

Media minitim kabar yang dikembangkan terdiri dari 1 penyangga, 1 tuas, 1 set kartu timbal, kartu konversi, kartu soal, dan replika benda konkrit. Media minitim kabar juga dilengkapi dengan buku petunjuk penggunaan media. Adanya buku petunjuk penggunaan media akan memudahkan siswa untuk memahami langkah-langkah yang harus dilakukan untuk menggunakan media minitim kabar. Apabila dalam pelaksanaan pembelajaran guru harus tetap mendampingi apabila siswa mengalami kesulitan.

Media ini didesain dengan warna yang mencolok dengan gambar-gambar yang menarik untuk menarik perhatian dan memotivasi siswa agar siswa belajar dengan senang. Kondisi belajar yang menyenangkan dapat mempengaruhi proses hasil belajar siswa. Sebagaimana yang diungkapkan oleh Munadi (2008: 24) bahwa ada dua faktor yang mempengaruhi hasil belajar siswa, salah satunya yaitu faktor psikologis yang meliputi intelegensi (IQ), perhatian, minat, bakat, motif, motivasi, kognitif, dan daya nalar peserta didik.

Bentuk media minitim kabar didesain dengan model timbangan gantung, hal ini dikarenakan menyesuaikan dengan bahan yang digunakan. Tuas miniatur timbangan terbuat dari hanger, sehingga pemakaiannya lebih mudah dengan cara digantung pada kayu penyangga. Tuas penimbang yang terbuat dari hanger dapat dilepas dan dipasang dengan mudah atau bersifat portable. Pemilihan bahan hanger plastik daripada logam (kawat) yaitu agar media lebih ringan, selain itu logam (kawat) yang dipakai secara terus menerus akan bengkok sehingga mempengaruhi proses dan hasil penimbangan yang kurang akurat.

Ada beberapa keunggulan media Minitim Kabar (miniatur timbangan kartu bergambar) dibandingkan dengan timbangan asli ataupun miniatur timbangan yang dijual di pasar, diantaranya: (1) didesain lebih menarik dengan adanya

Alifmatika: Jurnal Pendidikan dan Pembelajaran Matematika, Desember 2020, Vol. 2, No. 2 
gambar anak, warna yang mencolok yang disukai anak-anak pada usia 7-12 tahun; (2) terbuat dari bahan-bahan yang mudah didapatkan di lingkungan sekitar, sehingga pembuatannya dapat dilakukan oleh siapa saja; (3) bahan yang digunakan relatif ringan sehingga anak-anak mudah memindahkannya; (4) tuas timbangan bersifat portable yang dapat dilepas dan dipasang sehingga mudah disimpan dan tidak menghabiskan banyak ruangan, hal ini juga dapat melatih anak untuk mempersiapkan timbangan sendiri dan mengembalikan pada tempat semula; (5) media dibuat dengan ukuran yang lebih besar sehingga dapat digunakan secara kelompok maupun individu; (6) media minitim kabar dilengkapi dengan benda-benda konkrit untuk ditimbang sehingga ketika akan dipakai pendidik tidak kerepotan menyiapkan benda-benda untuk ditimbang, tetapi juga dapat menggunakan media lain untuk ditimbang.

Perbedaan media Minitim kabar dengan media timbangan yang lain yaitu media ini dilengkapi dengan kartu timbal yang terdapat tulisan satuan pengukuran berat seperti gram, ons, dan kg dengan ukuran yang berbeda-beda menyesuaikan besaran satuannya, sehingga ketika menimbang siswa dapat membaca satuan yang terdapat pada kartu dan memilih satuan sesuai kebutuhan. Media ini juga dilengkapi dengan kartu konversi dan kartu soal agar siswa dapat lebih mudah mengubah satuan. Kartu soal yang ada terdapat 11 model soal cerita yang dapat digunakan oleh siswa untuk latihan dengan menganalisis soal cerita terlebih dahulu terkait dengan kehidupan-sehari-hari.

\section{Kelayakan Media Minitim Kabar}

Hasil Validasi

Kelayakan media minitim kabar diketahui dari proses validasi dan tanggapan penggunaan media oleh siswa melalui angket respon siswa. Proses validasi media minitim kabar dilakukan kepada 2 ahli, yaitu yaitu ahli media dan ahli materi. Validasi ahli materi mencapai tingkat sangat baik dan tidak perlu direvisi dalam aspek materi dan penyajian. Validasi ahli media mencapai tingkat baik dan ada beberapa direvisi dalam aspek dan tampilan, sedangkan penggunaannya sudah baik.

Angket Respon Siswa

Angket respon siswa digunakan untuk mengukur kepraktisan media Minitim Kabar. Terdapat lima indikator angket respon siswa, yaitu penggunaan media, kemudahan pemahaman materi, visual (tampilan), minat dan motivasi, serta kepraktisan yang masing-masing indikator mendapat persentase 100\%. Sesuai hasil angket respon siswa, media minitim kabar ini relevan atau layak untuk digunakan dalam kegiatan belajar dan mengajar di Kelas II Sekolah Dasar. Selain itu, peneliti juga mengamati jalannya pembelajaran yang dilakukan oleh siswa dengan media Minitim Kabar. Siswa terlihat sangat antusias dalam pembelajaran menggunakan media Minitim Kabar. Siswa aktif dalam kelompok belajarnya, baik ketika uji coba media, maupun uji coba pemakaian.

\section{Peningkatan Hasil Belajar Kognitif Siswa Kelas II SD pada Materi Pengukuran Berat}

Media minitim kabar dapat membantu siswa dalam memahami materi pengukuran berat dengan satuan baku. Hal ini diketahui dari media minitim kabar

Alifmatika: Jurnal Pendidikan dan Pembelajaran Matematika, Desember 2020, Vol. 2, No. 2 
dapat meningkatkan hasil belajar kognitif pada siswa kelas II SD. Pada uji coba produk, rata-rata hasil belajar siswa meningkat sebanyak 43,53 dengan uji $N$-gain peningkatan hasil belajar sejumlah 0,6 dalam kategori sedang, dan pada uji coba lapangan rata-rata hasil belajar siswa meningkat sebanyak 45,06 dengan uji $\mathrm{N}$-gain peningkatan hasil belajar sejumlah 0,65 dalam kategori sedang.

Media Minitim Kabar dapat meningkatkan hasil belajar siswa karena kemampuan kognitif berasal dari sosial dan kultural. Perkembangan memori, nalar, dan perhatian melibatkan alat yang ada di masyarakat, seperti bahasa, sistem matematika, dan strategi memori (Vygotsky dalam Santrock, 2008: 60).

Media minitim kabar di dalamnya terdapat materi pengukuran berat yang terdiri dari satuan baku (kg, ons, gram). Satuan tersebut termasuk obyek abstrak, sehingga untuk mengenalkan kepada siswa harus melalui obyek konkrit terlebih dahulu. Sebagaimana Menurut (Piaget dalam Herliani and Heryati 2017: 63) anak pada usia 7-12 tahun berada pada tahap operasional konkret, artinya mampu berpikir logis mengenai objek dan kejadian meskipun masih terikat objek-objek yang bersifat konkret. Jadi dalam pembelajarannya siswa harus terlibat dalam benda-benda yang nyata.

Benda konkrit yang terdapat pada media minitim kabar menyerupai bentuk benda asli dan dapat digunakan secara langsung sehingga dapat menjadi perantara siswa dalam memahami pengukuran berat dengan satuan baku dari jenjang konkrit menuju pada abstrak. Sebagaimana kerucut pengalaman Dale dalam Daryanto (2010: 13) bahwa membuat jenjang konkrit-abstrak dengan dimulai dari siswa yang berpartisipasi dalam pengalaman nyata, kemudian menuju menjadi pengamat kejadian nyata, dilanjutkan ke siswa sebagai pengamat terhadap kejadian dengan media, dan terakhir siswa sebagau pengamat kejadian yang disajikan dengan simbol.

Menurut (Santrock, 2008: 351) bahwa pemahaman konseptual adalah kunci dari pembelajaran. Pengajaran yang penting adalah membantu murid memahami konsep utama dalam suatu subjek, bukan melalui fakta-fakta yang terpisah. Kegiatan menimbang dengan menggunakan media minitim kabar yang dilakukan siswa memungkinkan siswa untuk mengeksplorasi dalam konsep pengukuran berat. Konsep yang diperoleh berupa konsep membandingkan berat benda, mengurutkan, menganalisis, mengevaluasi, hingga mencipta.

Media minitim kabar di dalamnya terdapat latihan-latihan soal cerita kontekstual yang mengandung ranah kognitif mulai dari C1 sampai C6. Tujuan dari pengadaan soal tersebut bertujuan agar siswa tidak sekadar mempunyai pengetahuan satuan dalam pengukuran berat, akan tetapi mampu beradaptasi memecahkan masalah yang berkaitan dengan kehidupan sehari-hari. Menurut (Santrock, 2008: 134) intelegensi merupakan keahlian memecahkan masalah dan kemampuan beradaptasi dan belajar dari pengalaman hidup sehari-hari.

\section{KESIMPULAN}

Berdasarkan penelitian ini dapat disimpulkan bahwa pengembangan media Minitim Kabar (miniatur timbangan kartu bergambar) yang ditujukan kepada siswa kelas II SD menggunakan model penelitian yang dikembangkan oleh Sugiyono telah memenuhi 10 tahap pengembangan. Kelayakan media Minitim Kabar (miniatur timbangan kartu bergambar) dapat dilihat dari hasil penilaian

Alifmatika: Jurnal Pendidikan dan Pembelajaran Matematika, Desember 2020, Vol. 2, No. 2 
oleh ahli media dan ahli materi. Rata-rata rekapitulasi penilaian oleh validator ahli media adalah $87,5 \%$ berada pada kualifikasi baik. Sedangkan rata-rata rekapitulasi penilaian dari validator ahli materi adalah 91,6\% berada pada kualifikasi sangat baik. Hasil angket respon siswa yang meliputi segi penggunaan media, kemudahan pemahaman materi, visual (tampilan), minat dan motivasi, serta kepraktisan memperoleh persentase sejumlah $100 \%$.Hasil belajar kognitif siswa kelas II SD mengalami peningkatan setelah diberikan treatment menggunakan media minitim kabar (miniatur timbangan kartu bergambar) sebanyak 45,06. Hasil uji $N$-gain sebesar 0,65 berada pada tingkat sedang. Hal itu dikarenakan media minitim kabar dikembangkan dengan usia tahapan operasional konkret, sehingga anak dapat mempelajari sesuatu yang abstrak dengan media sesuatu yang nyata dan terlibat di dalamnya sehingga anak benar-benar paham dan dapat memecahkan soal melalui latihan soal cerita yang terkait dengan kehidupan sehari-hari.

\section{SARAN}

Berdasarkan hasil penelitian dan pengembangan, terdapat beberapa saran yaitu bagi peneliti selanjutnya dapat lebih memperhatikan penggunaan waktu sehingga lebih maksimal dalam pengambilan data. Dalam pembuatan media pembelajaran dapat ditingkatkan bahan-bahannya, tidak selalu menggunakan barang-barang bekas, akan tetapi bisa menggunakan sebagai pemanfaatan barang bekas untuk mengurangi limbah/ sampah. Bagi peneliti selanjutnya hendaknya dapat memilih strategi, metode, bahan ajar (buku lain) untuk memaksimalkan pengajaran materi pengukuran berat.

\section{UCAPAN TERIMA KASIH}

Kami mengucapkan terima kasih atas dukungan dari Program Studi Pendidikan Guru Sekolah Dasar, Fakultas Ilmu Pendidikan, Universitas Islam Raden Rahmat Malang.

\section{DAFTAR PUSTAKA}

Aini, N. (2017). Analisis Kesalahan Siswa Sekolah Dasar dalam Menghitung Berat Benda Menggunakan Tangga Konversi Berat. Universitas Muhammadiyah sidoarjo.

Aisyah, N. (2017). Pengembangan Pembelajaran Matematika SD. Jakarta: Depdiknas.

Ardila, A., \& Hartanto, S. (2017). Faktor Yang Mempengaruhi Rendahnya Hasil Belajar Matematika Siswa MTs Iskandar Muda Batam. Pythagoras: Jurnal Program Studi Pendidikan Matematika, 6(2), 175-186. https://doi.org/10.33373/pythagoras.v6i2.966

Arifin, Z. (2016). Evaluasi pembelajaran: Prinsip, teknik, dan prosedur. Bandung: PT Remaja Rosdakarya.

Ashikin, M. F. (2018). Pengembangan Media Penggaris Konversi Satuan Pengukuran Dalam Pembelajaran Matematika Di Kelas Tinggi Sdn Sindurejan Yogyakarta. Basic Education, 7(23), 214-225. 
Daryanto. (2010). Media Pembelajaran. Bandung: Satu Nusa.

Handayani, H., \& Alamsyah, S. (2017). Penggunaan Media Timbangan dalam Meningkatkan Aktivitas Dan Hasil Belajar Matematika pada Materi Perkalian Di Kelas II Sekolah Dasar. Golden Age: Jurnal Pendidikan Anak Usia Dini, 1(2), 61-68. https://doi.org/10.29313/ga.v1i2.3384

Herliani, E., \& Heryati, E. (2017). Modul pengembangan keprofesian berkelanjutan sd kelas awal terintegrasi penguatan pendidikan karakter dan pengembangan soal: a kelompok kompetensi. Jakarta: Kementerian Pendidikan dan Kebudayaan.

Maizar. (2016). Meningkatkan Kemampuan Pemahaman Konsep Satuan Berat Melalui Puzzle Kotak Bagi Anak Tunarungu di Kelas IV Center Kota Payakumbuh. E-JUPHEKhu (Jurnal Ilmiah Pendidikan Khusus), 5(2), 1-13.

Masyithoh, A. (2014). Pengembangan media papan pengukuran satuan panjang dan satuan massa untuk meningkatkan hasil belajar matematika. Skripsi. Universitas Islam Negeri Malik Ibrahim.

Munadi, Y. (2008). Media Pembelajaran Sebuah Pendekatan Baru. Jakarta: Gaung Persada Press.

Mutrofin, S. A., \& Mudjiarti, T. (2014). Meningkatkan Hasil Belajar Pengukuran Berat Dengan Media Timbangan Pada Siswa Kelas II Sekolah Dasar. Jurnal Penelitian Pendidikan Guru Sekolah Dasar, 2(3), 1-11.

Rufayda, I. (2013). Pengembangan Permainan Monopoli sebagai Media Pembelajaran Matematika Pada Materi Hubungan Antar Satuan Siswa Kelas III Di MI. ATTARAQQIE Kota Malang. Universitas Islam Negeri Malik Ibrahim Malang.

Santrock, J. W. (2008). Psikologi Pendidikan (terjemahan). Jakarta: Prenada Media Grup.

Sugiyono. (2011). Statistika Untuk Penelitian. Bandung: Alfabeta.

Sugiyono. (2015). Metode Penelitian Kualitatif, Kuantitatif, dan R\&D. Bandung: Alfabeta.

Widayanti, A. N. A. D., Fitrihidajati, H., \& Fauzia, A. N. M. (2016). Peningkatan Hasil Belajar Siswa Melalui Pembelajaran Berbasis Pendekatan Saintifik Pada Materi Kalor Dan Perpindahannya Pada Siswa Kelas Vii. Pendidikan Sains, 4(03), 1-5. 